\title{
PENGARUH RELAKSASI BENSON TERHADAP KUALITAS HIDUP PASIEN BREAST CANCER YANG MENJALANI KEMOTERAPI DI RUMAH SAKIT DR.MOEWARDI SURAKARTA
}

\author{
Eska Dwi Prajayanti, Irma Mustika Sari \\ STIKES ‘Aisyiyah Surakarta \\ eska_ners2012@yahoo.com
}

\begin{abstract}
ABSTRAK
Latar Belakang: Kanker adalah proses penyakit yang bermula ketika sel abnormal diubah oleh mutasi genetik dari Deoxyribo Nucleid Acid(DNA) seluler. Salah satu kanker yang paling sering menyerang wanita di seluruh dunia adalah breast cancer. Pasien kanker yang menjalani kemoterapi dapat mengalami perubahan berbagai aspek-aspek kehidupan yang akan berpengaruh terhadap kesehatan fisik, kesejahteraan psikologis, hubungan sosial dan lingkungan. Hal ini akan berdampak pada kualitas hidup pasien. Penelitian ini bertujuan untuk mengetahui pengaruh relaksasi Benson terhadap kualitas hidup pasien breast cancer yang menjalani kemoterapi di Rumah Sakit Dr. Moewardi Surakarta. Metode: desain penelitian Studi Quasi pra-posttest control satu desain kelompok eksperimental. Jumlah sampel dalam penelitian ini adalah 22 responden yang dipilih dengan menggunakan teknik purposive sampling. Sampel dibagi menjadi kelompok perlakuan dan kelompok kontrol sebagai salah satu responden dengan menangani sesuai dengan standar rumah sakit tanpa diberi relaksasi Benson. Hasil: ada terdapat pengaruh kualitas hidup antara pasien yang diberikan teknik relaksasi Benson dan pasien yang tidak mendapatkan teknik relaksasi Benson (sign. 2-tailed <0.05) pada domain I (KesehatanFisik), II (Psikologis) dan IV (Lingkungan). Kesimpulan: Terapi Relaksasi Benson adalah salah satu jenis teknik relaksasi yang dapat digunakan untuk meningkatkan kualitas hidup pasien breast cancer yang menjalani kemoterapi di Rumah Sakit Dr.Moewardi Surakarta.
\end{abstract}

Kata kunci: Kualitas Hidup, Breast cancer, Relaksasi Benson.

\section{ABSTRACT}

Background: Cancer is a disease process that begins when abnormal cells are altered by a genetic mutation of the cellular DeoxyriboNucleid Acid (DNA). One of the most common cancers in women around the world is Breast Cancer. Cancer patients undergoing chemotherapy may experience changes in various aspects of life that will affect physical health, psychological wellbeing, social and environmental relations. This will affect the quality of life of patients. This study aims to determine the effect of Benson relaxation on the quality of life of patientsbreast cancer who underwent chemotherapy at Dr. Hospital. Moewardi Surakarta. Methods: research design Quasi studies pre-posttest control an experimental group design. The number of samples in this 


\section{GASTER Vol. XV No. 2 Agustus 2017}

study were 22 respondents selected by using purposive sampling technique. The sample was divided into the treatment group and the control group as one of the respondents by handling in accordance with hospital standards without being given Benson relaxation. Result: There was an effect of quality of life between patients given Benson relaxationtechniques and patients not receiving Benson relaxation techniques (2-tailed sign $<0.05)$ on domain I (Physical Health), II (Psychological) and IV (Environment). Conclusion: Benson Relaxation Therapy is one type of relaxation technique that can be used to improve the quality of life of breast cancer patients undergoing chemotherapy at Dr. Moewardi Surakarta Hospital.

Keywords: Quality of Life, Ca Mamae, Benson Relaxation

\section{A. PENDAHULUAN}

Kanker adalah proses penyakit yang bermula ketika sel abnormal diubah oleh mutasi genetik dari Deoxyribo Nucleid Acid(DNA) seluler (Smeltzer \& Bare, 2001). Salah satu kanker yang paling sering menyerang wanita di seluruh dunia adalah $c a$ mamae. Kemoterapi merupakan pengobatan kanker dengan menggunakan obat-obatan atau hormon yang berbeda dengan terapi radiasi dan pembedahan. Tujuannya adalah untuk mencegah/menghambat multiplikasi sel kanker, menghambat invasi dan metastase (Aziz, Andriojo \& Saifudin, 2010). Pasien kanker yang menjalani kemoterapi dapat mengalami perubahan berbagai aspek-aspek kehidupan yang akan berpengaruh terhadap kesehatan fisik, kesejahteraan psikologis, hubungan sosial dan lingkungan. Hal ini akan berdampak pada kualitas hidup pasien
(Skevington, Lotfy \& Connell, 2004). Kualitas hidup semakin banyak digunakan sebagai ukuran untuk mengevaluasi efektivitas pengobatan (Dehkordi, 2011)

Upaya yang dilakukan untuk meningkatkan kualitas hidup adalah dengan menggunakan terapi modalitas komplementer seperti yoga, akupuntur, naturopati, terapi musik, interaksi pikiran tubuh dan relaksasi. Salah satu teknik relaksasi yang dapat digunakan adalah Relaksasi Benson. Relaksasi Benson adalah suatu jenis terapi untuk penanganan kegiatan mental dan menjauhkan tubuh dan pikiran dari rangsangan luar untuk mempersiapkan tercapainya hubungan yang lebih dalam dengan pencipta, yang dapat dicapai dengan metode hypnosis, meditasi yoga, dan bentuk latihan-latihan yang ada hubungannya dengan penjajakan pikiran (Martha, 2005). Penelitian yang dilakukan oleh Feyzi, et.al 
(2015) mengatakan bahwa terapi Benson yang dilakukan pada 60 orang yang sedang menjalani hemodialisis mampu meningkatkan kualitas hidupnya.

Studi pendahuluan yang dilakukaan di RSUD Dr.Moewardi Surakarta yang dilakukan pada 5 pasien Ca Mamae yang menjalani kemoterapi didapatkan 4 pasien memiliki kualitas hidup yang rendah dan 1 pasien memiliki kualitas hidup sedang setelah dilakukan pengukuran dengan menggunakan alat ukur WHOQOL. Ke 5 pasien mengatakan belum pernah mendapatkan terapi relaksasi selama kemoterapi. Dari hasil studi pendahuluan peneliti ingin membuktikan apakah dengan menggunakan terapi relaksasi Benson mampu meningkatkan kualitas hidup pasien Ca Mamae yag menjalani kemoterapi di RSUD Dr. Moewardi Surakarta.

\section{B. BAHAN DAN METODE}

Jenis penelitian ini adalah Quasy Eskperiment dengan desain penelitian yang digunakan adalah pre-postest control one group design.

Populasi dalam penelitian ini adalah seluruh klien ca mamae yang menjalani kemoterapi yang dirawat di ruang perawatan di Ruang kemoterapi RS Dr. Moewardi Surakarta sebanyak 22 klien.
Besar sampel yang diguakan dalam penelitian ini adalah 11 untuk kelompok perlakuan dan 11 untuk kelompok kontrol. penelitian dilaksanakan selama 1 bulan, yaitu dari bulan Mei 2017 - Juni 2017. Variabel independen dalam penelitian ini adalah teknik relaksasi Benson. Variabel dependen dalam penelitian ini adalah kualitas hidup pasien ca mamae yang menjalani kemoterapi

Instrumen pada penelitian ini adalah dengan menggunakanWHOQoL-BREF untuk menilai kualitas hidup.

\section{HASIL DAN PEMBAHASAN}

Penelitian yang dilakukan pada penderita Ca Mamae yang menjalani kemoterapi melalui intervensi teknik relaksasi Benson di Ruang Mawar 3 RSUD Dr. Moewardi Surakarta tahun 2017 , dengan total subjek sebanyak 22 pasien didapatkan hasil sebagai berikut

Tabel 3.Hasil Uji Wilcoxon Signed Rank Test

\begin{tabular}{ccc}
\hline Domain & $\begin{array}{c}\text { Sig.(2- } \\
\text { tailed) }\end{array}$ & Interpretasi \\
\hline I & 0.000 & H0 ditolak H1 diterima \\
II & 0.001 & H0 ditolak H1 diterima \\
III & 0.088 & H0 diterima H1 ditolak \\
IV & 0.000 & H0 ditolak H1 diterima \\
\hline
\end{tabular}

Pengaruh Relaksasi Benson terhadap ... 161 


\section{GASTER Vol. XV No. 2 Agustus 2017}

Hasil uji Wilcoxon Signed Rank Test menunjukkan terdapat pengaruh kualitas hidup antara pasien yang diberikan teknik relaksasi Benson dan pasien yang tidak mendapatkanteknik relaksasi Benson (sign. 2-tailed $<0.05$ ) pada domain I (KesehatanFisik), II (Psikologis) dan IV (Lingkungan). HasilujiWilcoxon Signed Rank Test juga menunjukkan tidakterdapat perbedaan kualitas hidup antara pasien yang diberikan teknik relaksasi Benson danpasien yang tidak mendapatkan teknik relaksasi Benson (Sign. 2-tailed $>0.05$ ) pada domain III (Sosial).

Hasil analisis bivariat menunjukkan bahwa terdapat pegaruh pemberian relaksasi benson terhadap kualitas hidup pasien ca mamae yang menjalani kemoterapi pada domain I yaitu kesehatan fisik. Pada pasien yang mengalami ca mamae akan merasakan nyeri pada area payudara. Pemberin relaksasi benson mampu menurunkan skala nyeri pada pasien ca mamae. Hal ini sejalan dengan penelitian yang dilakukan Purwanto, 2009 yang mengungkapkan bahwa pada kelompok yang mendapat teknik relaksasi Benson mengalami penurunan skala nyeri dikarenakan teknik relaksasi benson tersebut akan mempengaruhi sistem saraf simpatis dan para simpatis sehingga menyebabkan otot-otot menjadi rileks dan nyeri akan berkurang.

Relaksasi benson yaitu relaksasi yang melibatkan keyakinan yang dianutmempercepat keadaan menjadi relaks (kombinasi respon relaksasi dengan keyakinan) akan melipat gandakan manfaat yang didapat dari respon relaksasi. Salah satu manfaat teknik relaksasi benson adalah mengurangi rasa nyeri (Benson, 2000).

Pada domain 2 yaitu keadaan psikologis didapatkan bahwa ada pengaruh pemberian terapi benson terhadap kondisi psikologis pasien ca mamae yang menjalani kemoterapi. Kondisi psikologis yang dialami penderita ca mamae biasanya berupa kecemasan dalam menghadapi penyakitnya dan proses kemoterapi. Kemoterapi merupakan proses pengobatan yang panjang dan membutuhkan waktu yang lama. Hal ini menyebabkan reaksi seperti tidak berdaya, putus asa, cemas, depresif atau berontak dapat mendominasi sehingga efek segala tambahan daan penyulit semakin mengganggu.(Jong, 2004)

Kecemasan yang berat akan mempengaruhi sistem kerja saraf manusia yaitu hipotalamus yang berfungsi mengontrol dan mengatur sistem saraf otonom. Pada kondisi cemas, sistem syaraf ini akan mengeluarkan norrepineprin 


\section{GASTER Vol. XV No. 2 Agustus 2017}

melalui hasil sekresi pada ujung saraf yang berhubungan langsung dengan ujung organ yang dituju. Akibatnya frekuensi jantung meningkat, terjadi vasokontriksi perifer mengakibatkan tekanan darah meningkat. Rasa kesiapsiagaan menjadi lebih besar (Smeltzer\&Bare, 2001).

Salah satu terapi yang digunakan menurunkan cemas adalah relaksasi Benson (Djauhari dalam Green\&Setyowati,2004). Relaksasi Benson merupakan teknik relaksasi yang digabung dengan keyakinan yang dianut oleh pasien. Benson dan Poctor (2000) menjelaskan bahwa relaksasi Benson akan menghambat aktivitas saraf simpatis yang dapat menurunkan konsumsi oksigen oleh tubuh dan selanjutnya otot-otot tubuh menjadi relaks sehingga menimbulkan perasan tenang dan nyaman. Terapi relaksasi benson mampu menurunkan kadar kortisol yaitu hormon stress yang berkontribusi besar dalam tekanan darah tinggi.

Domain 3 Sosial, dalam penelitian ini teknik relaksasi Benson tidak mempengaruhi hubungan sosial pasien ca mamae yang menjalani kemoterapi. Dukungan sosial merupakan bentuk bantuan yang dirasakan seseorang yang dapat menumbuhkan perasaan nyaman, percaya diri, semangat, serta meningkatkan kesehatan mental seseorang yang dapat diperoleh melalui hubungan interpersonal. Sumber dukunga sosial yang terbesar datang dari orang yang berarti dan memiliki kedekatan emosional. Dukungan sosial mampu menurunkan kecemasan, gangguann umum, somatisasi dan depresi. Bentuk dukungan itu sendiri dapat berupa dukungan emosional, dukungan penghargaan, dukungan instrumental, dukungan informasi dan dukungan jaringan sosial( Safarino dalam Siswanto, Wardani\&Utami,1999). Dukungan sosial akan sanga bermanfaat apabila diberikan pada orang yang membutuhkan dan disaat tang tepat. Relaksasi benson sendiri merupkan tindakan mandiri yang dilakukan untuk menurunkan kecemasan pada diri seseorang sehingga proses ini tidak membutuhkan dukungan sosial dari pihak lain.

Domain IV Lingkungan, hasil penelitian menunjukkan ada pengaruh pemberian teknik relaksasi Benson terhadap dimensi lingkungan pasien ca mamae yang menjalani kemoterapi. Perasaan takut yang dialami oleh pasien ca mamae disebabkan oleh adanya kekhawatiran mereka terhadap kondisi kesehatan mereka. Kondisi penyakit yang dialami dan proses pengobatan menyebabkan timbulnya kesedihan pada pasien ca mamae. Kondisi ini menyebabkan pasien $\mathrm{Ca}$ mamae berusaha mencari cara untuk menhgibur diri 


\section{GASTER Vol. XV No. 2 Agustus 2017}

mereka. Salah satu caranya adalah dengan melakukan teknik relaksasi Benson.

\section{SIMPULAN DAN SARAN}

Simpulan: Penggunaan Teknik Relaksasi Benson dapat meningkatkan kualitas hidup pasien ca mamae yang menjalani kemoterapi meliputi dimensi fisik, psikologi dan lingkungan.

Saran: penelitian ini dapat dijadikan acuan sebagai salah satu teknik relaksasi yang dapat digunakan dalam dunia keperawatan.

\section{DAFTAR PUSTAKA}

Aziz, MF., Andrijono, Saifuddin AB, editors., 2010. Buku Acuan Nasional Onkologi Ginekologi. Edisi kedua.Jakarta: Yayasan Bina Pustaka Sarwono Prawirohardjo.

Bare BG., Smeltzer SC. 2001. Buku Ajar Keperawatan Medikal Bedah. Jakarta: EGC.

Benson, Herbert \& Proctor. (2000) Dasar-Dasar Respon Relaksasi. Edisi 1. Bandung: Kaifa

Datak, Gad. (2008). Pengaruh Relaksasi Benson Terhadap Nyeri Pasca Bedah Transurethral Resection of The Prostate di RSUP. FatmawatiJakarta. Depok: Program Pasca Sarjana Fakultas Ilmu Keperawatan Universitas Indonesia

Dehkordi, Heydarnejad, Fatehi. (2011). Quality of Life in Cancer Patients undergoing Chemotherapy.Diunduh dihttp://www.ncbi.nlm.nih.gov/pmc/articles/PMC3251183 pada tanggal 07 Januari 2017.

Feyzi Hossein, Paveh, BK., Hadadian F., Rezaie M. 2015. Investigating the effects og Benson's relaxation technique on quality of life among patients receiving hemodialysis. Iran J Crit Care Nurs. 2015;8 (1):13-20

Glimelius, B (2004) Quality of Life During Chemotherapy in Patiens with Symptomatic Advanced Colorectal Cancer. February 1, 2004, Volume 73, No.3. http://www.jeccr.com/ content/123/1/41

Ignatavicius, D.D et al. (2006), Medical Surgical Nursing, A Nursing Process Approach, 2nd edition, W.B. Saunders Company, Philadelphia 
Montazeri A. (2008). Health-related quality of lifein breast cancer patiens: A bibliographic review of the literatur from 1974 to 2007. Journal of Experimental \& Clinical Cancer Research. $\mathrm{http} / \mathrm{www} / . j \mathrm{jec}$.com/content/27/1/32

Purwanto., \& Zulekha (2007). Pengaruh Laihan Relaksasi Religius Untuk Mengurangi Insomnia di Yogyakarta. Universitas Muhammadiyah Surakarta

Sangadji, Faisal, Waluyo, Agung \& Gayatri, Dewi (2011) Pengaruh Relaksasi Benson Terhadap Intensitas Nyeri pada Pasien Sindrom Koroner Akut di Daerah Istimewa Yogyakart. Depok: Program Pasca Sarjana Fakultas Ilmu Keperawatan Universitas Indonesia

Smletzer, Suzanne C., \& Bare, Brenda G. (2009). Texbook of Medical Surgical Nursing. $\left(10^{\text {th }}\right.$. ed.) Vol 2. Philadelphia Lippincott William \& Wilkins.

Silitonga, R. (2007). Faktor-Faktor yang Berhubungan dengan Kualitas Hidup Penderita Penyakit Parkinson di Poliklinik Saraf RS dr Kariadi. Diunduh di http://eprints.undip.ac.id/19152/1/ ROBERT_SILITONGA.pdf pada tanggal 7 Oktober 2012

WHO. (2004). Quality of life-BREF. http://www.who.int/substanceabuse/research tools/ whoqolbref/en 